Journal of Fish Biology (1993) 42, 395-401

\title{
The role of Callionymus lyra and C. reticulatus in the life cycle of Lernaeocera lusci in Belgian coastal waters (Southern Bight of the North Sea)
}

\author{
P. A. Van Damme, D. Maer tens*, A. Arrumm, O. Hamerlynck $\dagger$ And \\ F. OLLEVIER \\ Laboratory for Ecology, University of Leuven, Zoological Institute, Naamsestraat 59, \\ B-3000 Leuven, * Rijksstation voor Zeevisserij, Ankerstraat 1, B-8400 Oostende and \\ $\uparrow$ Marine Biology Section, University of Gent, Ledeganckstraat 35, B-9000 Gent, Belgium \\ and Centre for Estuarine and Coastal Ecology, Vierstraat 28, NL-4401 EA Yerseke,
}

The Netherlands

(Received 2 March 1992, Accepted 12 July 1992)

\begin{abstract}
A survey of the dragonet Callionymus lyra and the reticulated dragonet $C$. reticulatus from Belgian coastal waters (Southern Bight of the North Sea) in June 1991 revealed $34 \%$ of dragonets infected with 1-7 Lernaeocera lusci. This same parasite infected $9 \%$ of the reticulated dragonets (mean intensity =1). Parasite size is host-size-dependent. Of the parasites collected from $C$. lyra $64 \%$ were gravid adults (substage $\mathrm{X}$ ), and a significant positive relationship between the number of eggs and axial length of the parasite was found. The parasites were overdispersed within the dragonet population $\left(s^{2} / m=1.67\right)$.
\end{abstract}

Key words: Callionymus reticulatus; Callionymus lyra; non-commercial fish; Lernaeocera lusci; host specificity; Belgian coast.

\section{INTRODUCTION}

The parasite faunas of many commercially important marine fish species have been studied extensively (Kinne, 1984), but little is known about the role of non-commercial fish species in the life cycle of marine parasites. This study investigates the role of the dragonet (Callionymus lyra L.) and reticulated dragonet (C. reticulatus C. \& V.) in the life cycle of Lernaeocera lusci, a mesoparasite which uses sole [Solea solea (Jordan \& Goss)] as its intermediate host and bib [(Trisopterus luscus (L.)] as its common definitive host (Slinn, 1970; Evans et al., 1983).

Callionymus lyra is a poorly known non-commercial fish species in the southern North Sea (Van der Veer et al., 1990). Although dragonets are widely distributed (Chang, 1951 $a$; Van der Veer et al., 1990) little information is available on their role in the marine ecosystem. Aspects of the biology of $C$. lyra have been presented recently by Van der Veer et al. (1990). C. reticulatus is less well known and information on this species is provided by Chang (1951b) and Boer (1971).

The occurrence of crustacean parasites on $C$. lyra has been reported on several occasions. Scott (1929) recorded adult L. lusci in the Irish Sea and Hansen (1923), Stekhoven (1936) and Kabata (1958) reported impregnated Lernaeocera spp. on C. lyra. Despite the high number of occasional records, Kabata (1979) states that the dragonet "does not play an important part in the life cycle of Lernaeocera spp." Lernaeocera lusci has not been reported on the reticulated dragonet. 

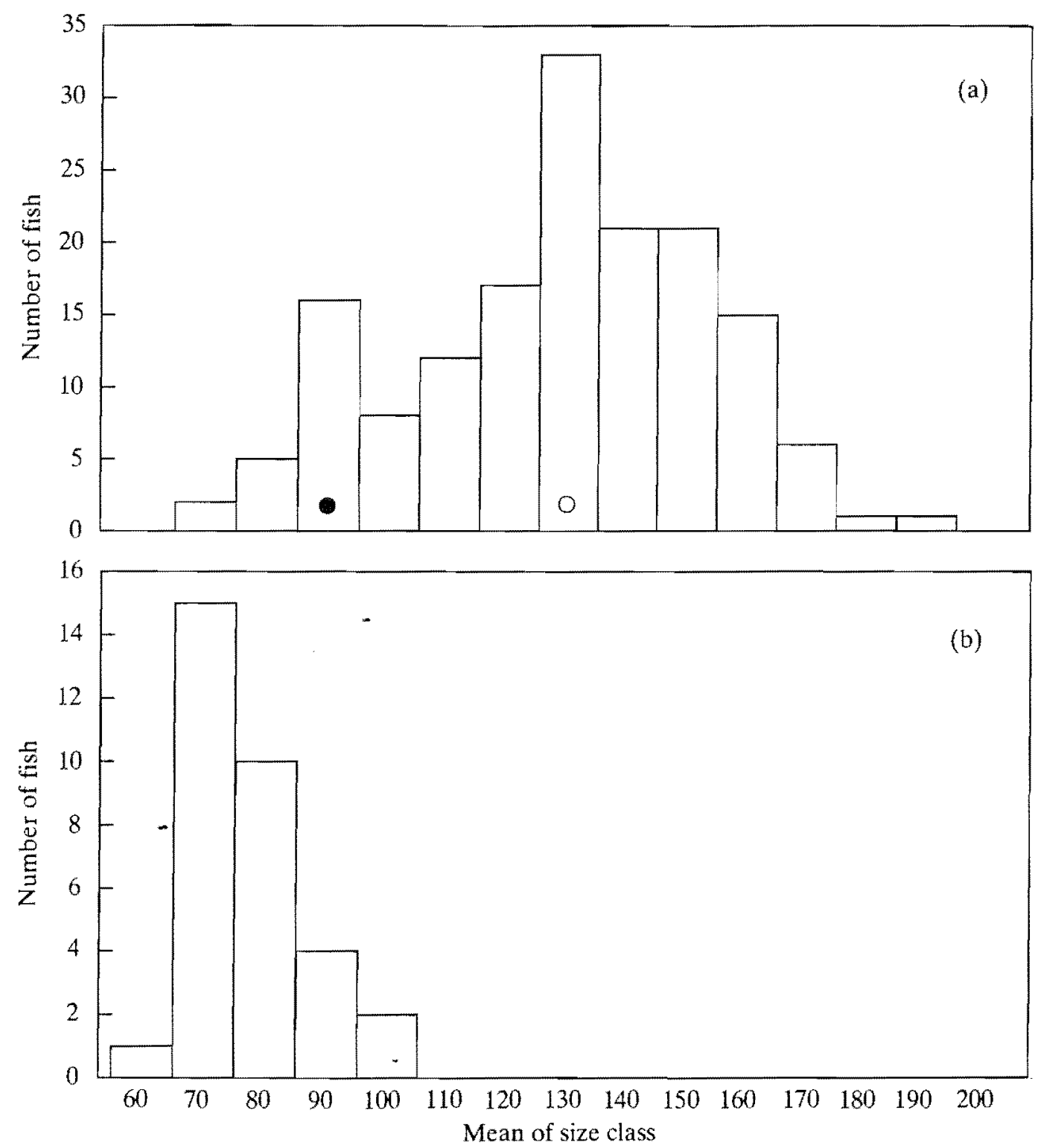

FIG. 1. Length-frequency distributions of Callionymus lyra (a) and C. reticulatus (b) in June $199 \mathrm{I}$ in Belgian coastal waters. Age-groups of $C$. lyra are indicated (by eye).

- I-group; $\mathrm{O}=$ II-group.

Most records of $L$. lusci on uncommon hosts (reviewed by Kabata, 1960, 1979) are anecdotal, and quantitative observations are largely unavailable. However, estimates of the ecological significance of the broad host specificity of $L$. lusci can only be made when sufficient quantitative data are provided.

This study presents data on the prevalence and the abundance of $L$. lusci $i$ on the dragonet and the reticulated dragonet in the Belgian Coastal Waters in June 1991, and estimates the possible role of these host species in the life cycle of $L$. lusci at the Belgian coast.

\section{MATERIAL AND METHODS}

During a summer survey (15 June 1991) with a research vessel 159 dragonets were collected in Belgian coastal waters $\left(51^{\circ} 28^{\prime} 27 \mathrm{~N}, 03^{\circ} 03^{\prime} 48 \mathrm{E}\right)$. Thirty-two C. reticulatus were collected from a nearby locality $\left(51^{\circ} 30^{\prime} 00 \mathrm{~N}, 03^{\circ} 00^{\circ} 00 \mathrm{E}\right)$.

Fish were preserved in $8 \%$ formalin immediately after capture. After 6 months fish were measured (total length: T.L.) and transferred to $70 \%$ ethanol. Figure 1 shows the 
TABLE I. Classification of adult female Lernaeocera lusci on Callionymus lyra (after Van Damme \& Hamerlynck, 1992)

\begin{tabular}{ll}
\hline Substage & \multicolumn{1}{c}{ Definition } \\
\hline Pennella $(\mathrm{P})$ & No flexure or one point of flexure \\
Immature $(\mathrm{U})$ & Two or three points of flexure \\
Mature pregravid $(\mathrm{W})$ & Genital region fully swollen \\
Mature gravid $(\mathrm{X})$ & External egg strings present \\
$\mathrm{X} 1$ & Immature eggs \\
$\mathrm{X} 2$ & Mature pigmented eggs \\
$\mathrm{Y}$ & External egg strings partly or completely \\
& spent \\
Dead parasite $(\mathrm{Z})$ & Remains of holdfast embedded in host \\
& tissue \\
\hline
\end{tabular}

length distributions of both the dragonets and the reticulated dragonets. The significant overlap of the lengths of different age groups of $C$. lyra and $C$. reticulatus made age-specific comparisons impossible. Therefore, the $C$. lyra were assigned to four length classes of between 70 and $185 \mathrm{~mm}$.

The skin, mouth cavity and gill cavity of the fish were checked for crustacean parasites. The staging of the adult female $L$. lusci on the hosts was based on the nomenclature of Van Damme \& Hamerlynck-(1992), which is a modification of the staging system of Sproston \& Hartley (1941). A summary of the diagnostic characters of each substage is given in Table I. The terms prevalence, mean intensity and abundance are used as recommended by Margolis et al. (1981).

The effect of host size on parasite axial length (AL; measured along axis between the basis of the mouth cone and the posterior end) was studied by linear regression. Fifty-four Lernaeocera (X substages) collected from dragonets were measured for this purpose.

The variance to mean ratio $\left(s^{2} / m\right)$ was calculated to measure the degree of dispersion of Lernaeocera within the $C$. lyra population (Elliott, 1971). Chi-square tests on the $s^{2} / m$ ratios were used to measure dispersion. The observed frequencies were then compared with the expected frequencies of the negative binomial distribution. A non-parametric test (Kruskal-Wallis) was used to determine whether significant differences in parasite abundance occurred between the size groups.

\section{RESULTS}

Lernaeocera lusci collected from $C$. lyra and $C$. reticulatus were identified by the presence of antennary processes (Kabata, 1979). Recently, Tirard (1991) has shown that the presence of antennary processes is a valid criterion to distinguish L. lusci from L. branchialis.

Thirty-four per cent of dragonets collected in June 1991 were infected with Lernaeocera lusci. Most (98\%) were attached in the mouth and gill cavities. Only $2 \%$ were attached to the skin. About $9 \%$ of reticulated dragonets were infected with L. lusci.

The overall mean intensity of infection on $C$. lyra was 1.76 and a maximum number of seven parasites was found on a fish of $166 \mathrm{~mm}$ total length. The variance to mean ratio is greater than unity $\left(1.67, \chi^{2}=380, P<0.01\right)$ revealing that the parasites were overdispersed within the $C$. lyra population. The observed distribution can be described by the negative binomial model $(k=0.48$; goodness-of-fit, 
TABLE II. Abundance, prevalence and variance to mean ratio of Lernaeocera lusci on Callionymus lyra belonging to different size classes (June 1991) in the southern North Sea

\begin{tabular}{lcccc}
\hline $\begin{array}{l}\text { Size } \\
\text { classes }\end{array}$ & $N$ & $\begin{array}{c}\text { Prevalence } \\
(\%)\end{array}$ & Abundance & $s^{2} / m$ \\
\hline$<100 \mathrm{~mm}$ & 31 & $25 \cdot 8$ & $0 \cdot 36$ & $1 \cdot 79^{*}$ \\
$101-125 \mathrm{~mm}$ & 43 & $37 \cdot 2$ & 0.51 & $1 \cdot 22$ \\
$126-150 \mathrm{~mm}$ & 52 & 38.5 & 0.64 & $1.79^{*}$ \\
$>150 \mathrm{~mm}$ & 28 & 33.3 & $1 \cdot 15$ & $3.61^{*}$ \\
\hline
\end{tabular}

*Variance to mean ratios significantly different from 1 .

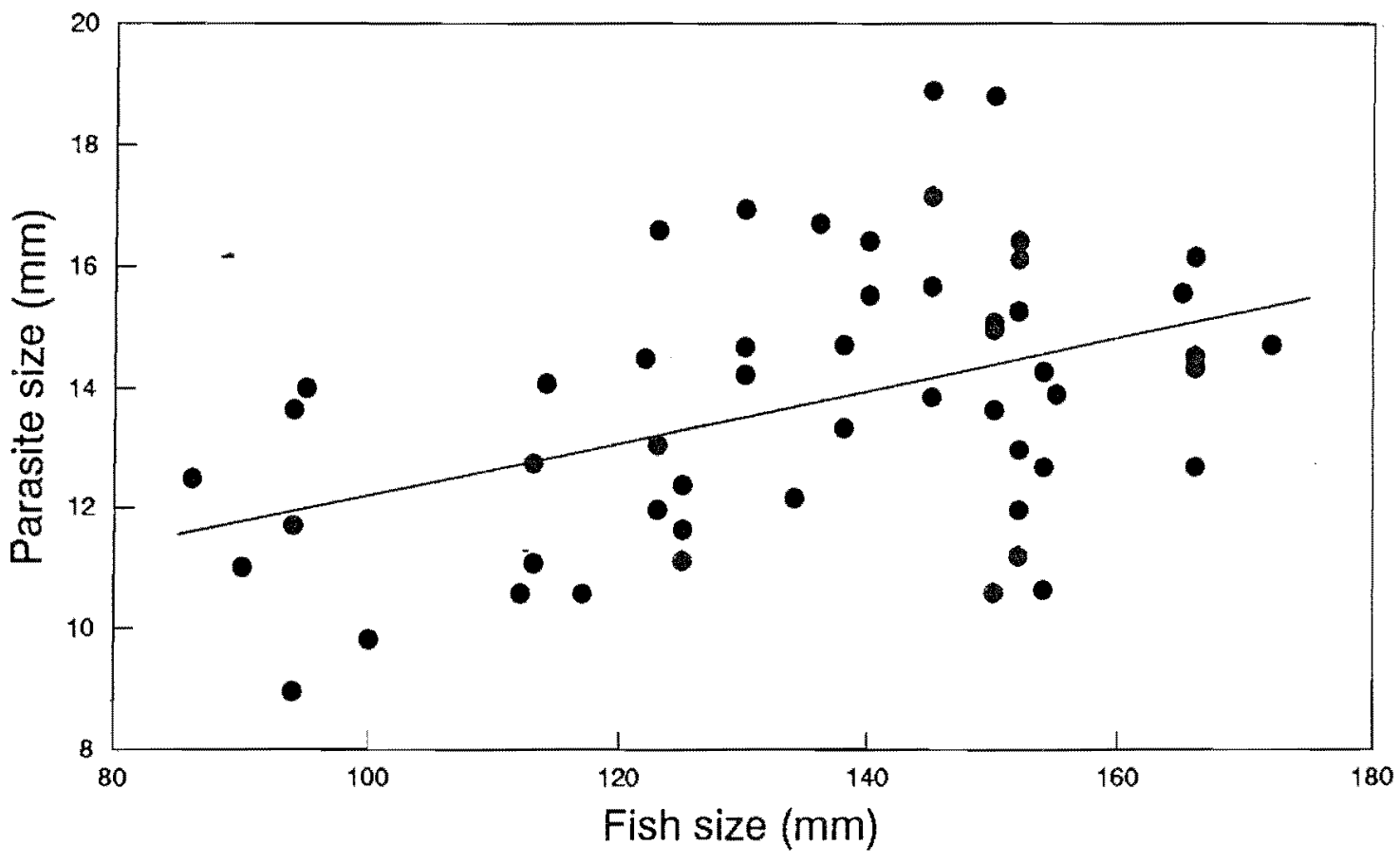

FIG. 2. Relationship between fish host length and parasite length for Lernaeocera luscion the dragonet. The linear equations are given in the text.

$\chi^{2}=5 \cdot 18$, d.f. $=6, P>0 \cdot 05$ ). The mean intensity and prevalence of $L$. lusci on dragonets of different size classes are presented in Table II. Prevalence was highest for dragonets between 100 and $150 \mathrm{~mm}(c .38 \%)$ and was lowest in, respectively, the smaller $(<100 \mathrm{~mm})$ and the larger size classes $(>150 \mathrm{~mm})$. There were no significant differences in the abundance of $L$. lusci among size classes of $C$. lyra (Kruskal-Wallis; $P>0.05$ ). In three of four size classes the parasite populations were significantly overdispersed (Table II).

Lernaeocera lusci collected from dragonets of variable length were measured (Fig. 2): there was a significant positive relationship between total length of the fish (TL) and axial length of the parasite (AL) $\left(\mathrm{AL}=8.065+0.042 \mathrm{TL}, r^{2}=0.174\right.$, $F=10 \cdot 75, P<0 \cdot 01)$. 


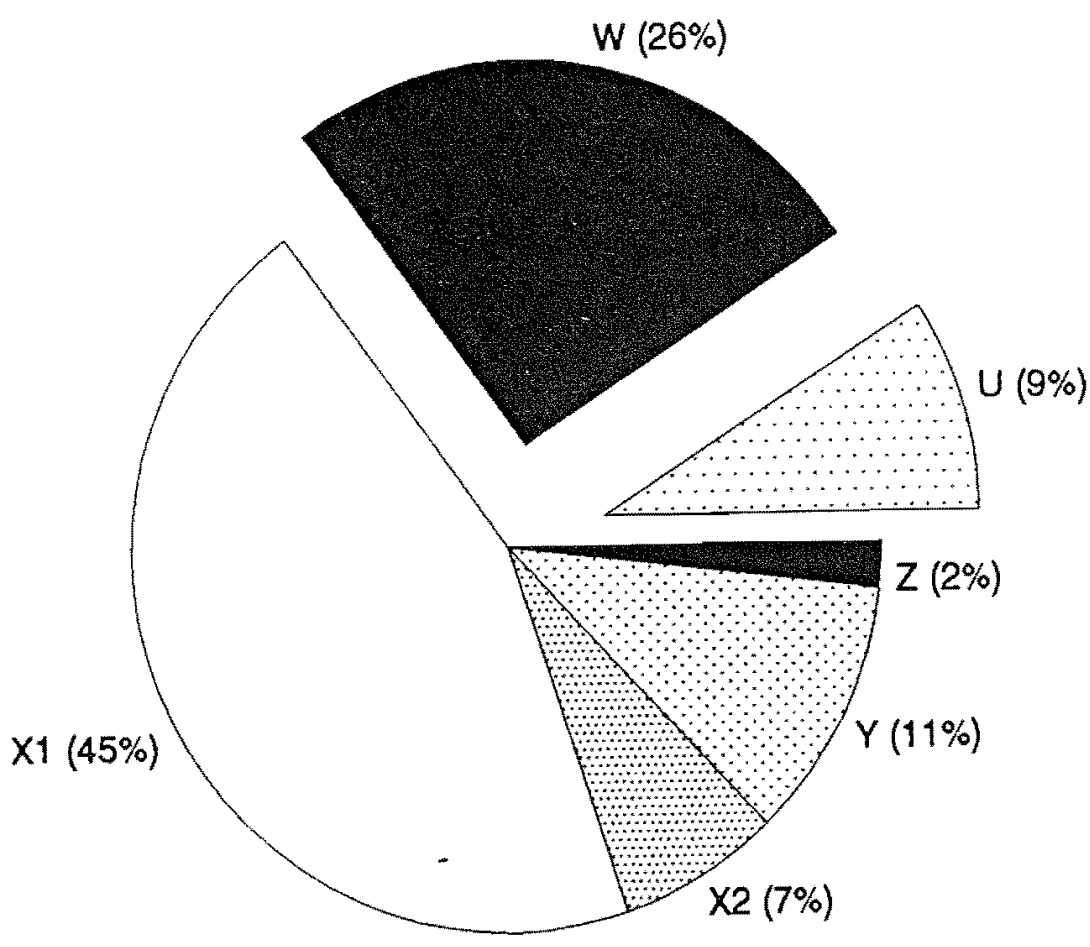

FIG. 3. Population structure of Lernaeocera lusci on Callionymus lyra $(n=45)$ at the Belgian coast (June 1991). For description of the substages see Table I. The slices of the immature stages have been set apart.

The population structure of $L$. lusci on C. lyra is presented in Fig. 3. Juvenile stages (P1 and $\mathrm{P} 2$ ) were not found, indicating either low transmission levels prior to fish capture or the short duration of this stage. The mean number of eggs of the X1/X2 substages collected from C. lyra was 517 (minimum 286, maximum 1400). There is a significant linear relationship between the axial length of the parasite (AL) and the number of eggs ( $\ln (\mathrm{eggs})=5.614+0.06 \mathrm{AL} ; F=4.729, P<0.05)$.

Of the three parasite specimens which were collected from the reticulated dragonet two belonged to the $\mathrm{W}$ substage and one belonged to the $\mathrm{X} 2$ substage.

\section{DISCUSSION}

Euzet \& Combes (1980) define host specificity as euryxenic when parasites are found in different host species which are not related phylogenetically. Rohde (1981) noted that parasites which exhibit euryxenic host specificity usually infect one species more heavily than others. Thus, adult female $L$. lusci show a clear preference for Trisopterus luscus (Slinn, 1970; Kabata, 1979), and other hosts are only occasionally parasitized. So far, there were a high number of anecdotal records of $L$. lusci on uncommon hosts (for a review, see Kabata, 1960, 1979), but, apart from Boxshall (1974), quantitative observations are largely missing. Yet, the present study illustrates that the ecological significance of occurrences on uncommon hosts should not be underestimated. Kabata (1960) noted that such occurrences may be very important in enabling certain species to survive or extend their distribution.

A range of hypotheses can be put forward to explain overdispersion in marine fish parasites. In the present study, the aggregated pattern of $L$. lusci on $C$. lyra 
may be due partly to the differences in parasite abundance among size (and hence age) classes of this fish species. Though no significant differences were found smaller fish harboured fewer parasites than larger fish (Table II). However, in comparison with fish between $100 \mathrm{~mm}$ and $150 \mathrm{~mm}$ in length, a lower prevalence was found for fish larger than $150 \mathrm{~mm}$. Testing of explanatory hypotheses for these observations is complicated by the paucity of information on migratory habits of the dragonet.

The population structure of $L$. lusci on $C$. lyra is characterized by the high number of parasites with egg strings $(X)$. Some of the parasites may have overwintered with the fish. Indeed it was found that C. lyra collected in March 1991 harboured ovigerous females (P. A. Van Damme, unpubl.). A minority of the parasites collected during the present study $(34 \%)$ nevertheless were in immature substages $\mathrm{U}$ and $\mathrm{W}$, which suggests that transmission also occurred shortly before sampling.

Dragonets and reticulated dragonets are found in water less than $50 \mathrm{~m}$ deep (Van der Veer et al., 1990). Boer (1971) reported that the reticulated dragonet is more common outside the coastal area while the dragonet is more common within. Therefore, C. reticulatus probably plays a less important role in the life cycle of $L$. lusci, which is typically a coastal parasite species (Kabata, 1979; Tirard \& Raibaut, 1989). The observation (O. Hamerlynck) that reticulated dragonets are less common on soft sandy bottoms, the preferred habitats of dragonets and soles, might also reduce their significance as final host in the life cycle of $L$. lusci.

Parasites belonging to the genus Lernaeocera show a variable degree of pathogenicity towards their final hosts, some of which (such as Trisopterus luscus, Merlangius merlangus and Gadus morhua) are of economic importance (Kabata, 1981). The assumption that non-commercial fish species, such as the dragonet, play an important role in the life cycle of these pathogenic parasite species may lead to a re-appraisal of their role in the North Sea ecosystem.

This study was supported by FKFO project no. 8.0086.88. The first author was supported by the National Science Foundation of Belgium (NFWO). This is contribution no. 618 of the Netherlands Institute for Ecology, Centre for Estuarine and Coastal Ecology, The Netherlands.

\section{References}

Boer, P. (1971). The occurrence of Callionymus reticulatus in the Southern North Sea. Journal du Conseil 33, 506-509.

Boxshall, G. A. (1974). Infections with parasitic copepods in North Sea marine fishes. Journal of the Marine Biological Association of the United Kingdom 54, 355-372.

Chang, H. W. (1951a). Age and growth of Callionymus lyra L. Journal of the Marine Biological Association of the United Kingdom 30, 281-296.

Chang, H. W. $(1951 b)$. On Callionymus reticulatus C. \& V. and its distribution in European seas. Journal of the Marine Biological Association of the United Kingdom 30, 297-312.

Elliott, J. M. (1971). Some methods for the statistical analysis of samples of benthic invertebrates. Scientific Publication of the Freshwater Biological Association, no. 25.

Euzet, L. \& Combes, C. (1980). Les problèmes de l'espèce chez les animaux parasites. Dans "Les problèmes de l'espece dans le règne animal". Mémoires de la Société Zoologique de France 40, 239-285. 
Evans, N. A., Whitfield, P. J., Bamber, R. N. \& Espin, P. M. (1983). Lernaeocera lusci (Copepoda: Pennellidae) on bib (Trisopterus luscus) from Southampton Water. Parasitology 86, 161-173.

Hansen, H. J. (1923). Crustacea Copepoda II. Copepoda parasita and hemiparasita. Danish Ingolf-Expedition 3, 1-92.

Kabata, Z. (1958). Lernaeocera obtusa n.sp.; its biology and its effects on the haddock. Marine Research Scotland 3, 1-26.

Kabata, Z. (1960). On the specificity of Lernaeocera (Copepoda parasitica). Annals and Magazine of Natural History 13, 133-139.

Kabata, Z. (1979). Parasitic Copepoda of British Fishes. London: The Ray Society.

Kabata, Z. (1981). Copepoda (Crustacea) parasitic on fishes: problems and perspectives. Advances in Parasitology 19, 1-71.

Kinne, O. (1984). Diseases of Marine Animals, Vol. IV, Part 1: Pisces. Hamburg: Biologische Anstalt Helgoland.

Margolis, L., Esch, G. W., Holmes, J. C., Kurie, A. M. \& Schad, G. A. (1981). The use of ecological terms in parasitology. Journal of Parasitology 68, 131-133.

Rohde, K. (1981). Ecology of Marine Parasites. St. Lucia: University of Queensland Press.

Scott, A. (1929). The copepod parasites of Irish Sea fishes. Proceedings and Transactions of the Liverpool Biological Society 43, 81-119.

Slinn, J. D. (1970). An infestation of adult Lernaeocera (Copepoda) on wild sole, Solea solea, kept under hatchery conditions. Journal of the Marine Biological Association of the United Kingdom $\mathbf{5 0 , 7 8 7 - 8 0 0 . ~}$

Sproston, N. G. \& Hartley, P. H. T. (1941). The ecology of some parasitic copepods of gadoids and other fishes. Journal of the Marine Biological Association of the United Kingdom 25, 361-392.

Stekhoven, J. H. Schuurmans (1936). Copepoda parasitica from the Belgian coast, II. Mémoires du Muséé royale d'Histoire naturelle de la Belgique 74, 1-20.

Tirard, C. (1991). Biodiversité et biogeographie evolutive dans les systèmes hôtes-parasites: le modèle Gadiformes (Téléostéens) —Copépodes et Monogènes. Thèse de doctorat, Université de Montpellier, France.

Tirard, C. \& Raibaut, A. (1989). Quelques aspects de l'écologie de Lernaeocera lusci (Bassett-Smith, 1896), copépode parasite de poissons Merlucciidae et Gadidae. Bulletin d'Ecologie 20, 289-294.

Van Damme, P. A. \& Hamerlynck, O. (1992). The infection dynamics and dispersion pattern of Lernaeocera branchialis L. on $0+$ whiting (Merlangius merlangus $\mathrm{L}$.) in the Oosterschelde (SW Netherlands). Journal of Fish Biology 41, 265-275.

Van der Veer, H., Creutzberg, F., Dapper, R., Duineveld, G. C. A., Fonds, M., Kuipers, B. R., Van Noort, G. J. \& Witte, J. I. (1990). On the ecology of the dragonet Callionymus lyra L. in the southern North Sea. Netherlands Journal of Sea Research 26, 139-150. 
